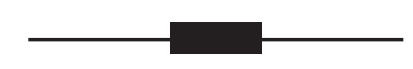

\title{
The Making of Conservation Science
}

\author{
Report on the Brill-Nuncius Seminar on the Material and \\ Visual History of Science, organized by Sven Dupré \\ (Utrecht University/University of Amsterdam) and \\ Esther van Duijn (Rijksmuseum Amsterdam), \\ 29-30 April 2021
}

\author{
Tijana Žakula
}

On 9 October 1947, the National Gallery in London opened the Exhibition of Cleaned Pictures. Some seventy masterpieces that had undergone various treatments since 1936 were brought together and exhibited in this groundbreaking show. Much criticized, but also praised by many, the exhibition sparked the so-called "cleaning controversy." It goes without saying that both the exhibition as well as the ensuing controversy impacted generations of scholars of all stripes. So much so that the exhibition was mentioned in virtually all the lectures that were delivered during the Brill Nuncius seminar held on 29-30 April 2021, which focused on the formation of conservation science in the post-World War II period, from the 1940s through the 1970s.

Organized by Sven Dupré and Esther van Duijn, under the auspices of the Descartes Centre, this fascinating seminar provided an overview of the history and development of conservation science in Western Europe: from Belgium to the United Kingdom, France, Germany, Italy, the Netherlands, and Spain. It hosted, addressed, and scrutinized diverse protagonists of this exceptionally complex field, including scientists and science policy-makers, collectors and conservators, museum professionals, and administrators. Inextricably linked with the advancement of technology, conservation science seems to have entered temples of art quite timidly. This happened, first and foremost, through a handful of erudite individuals, who had obtained their degrees in chemistry, but who also happened to have had a knack for art history. They had the best chance of survival in a world that was traditionally suspicious, or downright belligerent, towards science.

The keynote lecture was delivered by the historian of science Geert van Paemel, who focused on the advent and development of conservation science in Belgium. He compared and contrasted Paul Coremans (1908-1965), a chemist who proposed a multidisciplinary approach to the study of artwork, and the art historian Paul Philippot (1925-2016), who, inspired by the work of Cesare Brandi, developed a critical theory of art preservation, in which the conservator maintained the central role. Afterwards, Jo Kirby, a seasoned practitioner, took the audience on a tour of the National Gallery, tracing a path of the constantly moving science department. While curators happily remained housed in their offices overlooking Trafalgar Square, scientists' fate, 
as well as their premises, were constantly shifting in the period from 1949, when Joyce Plesters (1927-1996) was permanently employed to conduct research into pigments and varnishes, until 1977, a year which saw the appearance of the first issue of the National Gallery Technical Bulletin. This series has documented developments in scientific examination and conservation, as well as an ever-growing collaboration with art historians. It bore witness to a process of thorough integration of the scientific department into the DNA of the National Gallery, where disciplinary boundaries have, however, remained respected.

The development of conservation science in France from 1946 to 1970 was inseparable from the name and work of Madeleine Hours (1913-2005). An account of Hours's professional trials and tribulations was related by Camille Bourdiel, who traced the path of this indefatigable scholar and demonstrated that it was thanks to Hours that conservation science took root in France and eventually become indispensable in museum practice. Michael von der Goltz's lecture aptly showed that in post-war West Germany conservation science was lagging behind, primarily because Kurt Wehlte (1897-1973) considered conservation to be a mere craft, and kept scientific insights at bay. The most common practice was the transferal of paintings to a different support, owing to the adherence to an old-fashioned hierarchy of objects. It was in the course of the 1960s, however, that several important publications challenged this view and showed the importance of hard sciences in the domain of conservation. This attitude led to a further professionalization of this truly interdisciplinary field that fully integrated craft, science, and the humanities.

Scientific advances were essential to the development of preventative conservation, too. This was especially so in the domain of heating, ventilation, and air conditioning (HVAC), which contributed to a better understanding of "the ideal of the ideal environment," as Andrea Luciani (2021) wittily titled his lecture focusing on the history of climatology and conservation in museums from the 1940s till the 1980s. Science was at the heart of Ron Spronk's lecture as well, who detailed the early history of infrared photography and infrared reflectography, with an emphasis on the influential work of J. R. J. van Asperen de Boer (1935-2020).

Much to the surprise of the attendees, the last speaker, Salvador Muñoz-Viñas, called into question the very legitimacy of conservation science. While trying to demonstrate that the impact of conservation science on carrying out hands-on conservation and restoration tasks was much smaller than one may realize, he, in fact, tapped into the very core of what constitutes the scientific method and makes it relevant to practitioners: building knowledge based on constant experimentation. Conservation science is dead; may conservation science live long and prosper, and keep sparking controversy, one might say. What became eminently clear, though, was that this incredibly complex field and its various approaches definitely call for a critical historical scrutiny. And indeed, this Brill Nuncius seminar may well have provided an excellent starting point.

\section{REFERENCES}

Luciani, Andrea. "'The ideal of the ideal environment': The influence of climate control on the emergence of preventive conservation theories." Paper presented at The Making of Conservation Science: Brill-Nuncius Seminar on the Material and Visual History of Science, 29-30 April 2021.

The Burlington Magazine. 2015. "The Burlington Magazine and the National Gallery Cleaning Controversy," The Burlington Magazine Index Blog. https://burlingtonindex.wordpress.com/2015/07/11/ the-burlington-magazine-and-the-national-gallery-cleaning-controversy-1947-1963/ (accessed 3 June 2021). 